\title{
Ethoxylated Fatty Esters as Corrosion Inhibitors for Copper in Nitric Acid Solutions
}

\author{
H.E. Megahed \\ Dept. of Chemistry, Faculty of Science, Benha University, Benha, Egypt
}

Received 17 April 2011; accepted17 May 2011

\begin{abstract}
The effect of five compounds of ethoxylated fatty esters with different number of ethylene oxide units on the corrosion of copper in $1 \mathrm{M} \mathrm{HNO}_{3}$ solution has been studied using weight loss and galvanostatic polarization techniques. The inhibition efficiency was found to increase with increasing concentration and number of ethylene oxide units per molecule. Inhibition effect was explained on the basis of adsorption of ethoxylated fatty esters on the metal surface through their ethoxy groups. The adsorption process was found to follow Temkin adsorption isotherm. Polarization data suggested that the used additives act as mixed type inhibitors. It was found also that the ethoxylated fatty esters provide a good protection to copper against pitting corrosion in chloride containing solutions.
\end{abstract}

Keywords: copper, ethoxylated fatty esters, corrosion inhibitors, pitting corrosion, adsorption.

\section{Introduction}

Copper is a metal that has a wide range of applications due to its good properties. It is used in electronics, for production of wires, sheets, tubes and also to form alloys. Copper is resistant toward the influence of atmosphere and many chemicals; however, it is known that in aggressive media it is susceptible to corrosion. The use of copper corrosion inhibitors in such conditions is necessary since no protective passive layer can be expected. The possibility of copper corrosion prevention has attracted many researchers, having already been investigated numerous possible inhibitors. Amongst them there are inorganic ones [1], but in much greater numbers there are organic compounds and their derivatives [2-12]. It is noticed that the presence of heteroatoms such as nitrogen, sulphur or oxygen, in organic compounds, improves its action as copper corrosion inhibitor. This is explained by the presence of vacant $d$ orbital in copper ions that from coordinative bonds with atoms able to donate electrons.

\footnotetext{
* Corresponding author. E-mail address: helmymegahed@yahoo.com
} 
Interaction with rings containing conjugated bonds, $\pi$-electron, is also present [13].

Surfactant compounds are widely employed to protect some metals and alloys against corrosion [14-18]. The efficiency of the inhibition depends on the inhibitor concentration.

The aim of the present work is to investigate the inhibitive effect of ethoxylated fatty esters (non ionic surfactants) on the corrosion of copper in nitric acid solution using weight loss and galvanostatic polarization measurements.

\section{Experimental}

The copper test sample used has the chemical composition (wt \%) $0.001 \mathrm{Sn}$, $0.001 \mathrm{Ag}, 0.01 \mathrm{Fe}, 0.005 \mathrm{Bi}, 0.002 \mathrm{~Pb}$ and the remainder in $\mathrm{Cu}$. Prior to each experiments the specimen was polished with deferent grade emery papers. Then the specimen was washed with bidistilled water acetone and finally dried. All chemicals were analytical grade quality. A solution of $2 \mathrm{M} \mathrm{HNO}_{3}$ was prepared with bidistilled water.

For weight loss measurements the tested specimens were used in the form of sheets of dimension $1 \times 3 \times 0.2 \mathrm{~cm}$. For galvanostatic studies and potentiodynamic anodic polarization a cylindrical rod embedded in araldite with an exposed surface area of $0.32 \mathrm{~cm}^{2}$ was used.

Weight loss measurements were carried out as described elsewhere [19]. Galvanostatic polarization study has been performed with an EG \& G model 173 potentiostat /galvanostat equipment. A three compartments cell with a saturated calomel electrode and a platinum foil as auxiliary electrode was used. Potentiodynamic anodic polarization technique was performed at scanning rate of $1 \mathrm{mV} / \mathrm{s}$ using a Wenking potentioscan type POS73 and the current densitypotential curve was recorded in an X-Y recorder type PL3. The potentials were measured relative to saturated calomel electrode (SCE) and the electrolytic cell is described elsewhere [20].

\section{Materials}

Ethoxylated fatty esters were prepared by a previously simple described method [21] and having general formula $\mathrm{R}-\mathrm{COO}\left(\mathrm{CH}_{2}-\mathrm{CH}_{2}-\mathrm{O}\right) \mathrm{n}-\mathrm{H}$, where $\mathrm{R}$ is $\mathrm{C}_{18} \mathrm{H}_{37}$ and $\mathrm{n}$ is the number of moles of ethylene oxide (E.O) and equal 4, 6, 8, 10 and 12 for compounds I, II, III, IV and V, respectively.

\section{Results and discussion}

The effect of addition of five compounds of ethoxyalted fatty esters on the weight loss of copper coupons in $1.0 \mathrm{M} \mathrm{HNO}_{3}$ as corrosive medium after 3 hours was studied.

The percentage inhibition efficiency (I.E\%) and the parameter $(\theta)$ that represents the fraction of surface area covered by inhibitor molecules were calculated using the following equation 
$\mathrm{I} . \mathrm{E} \%=\left[1-\frac{W_{\text {add }}}{W_{\text {free }}}\right] 100$

$\theta=\left[1-\frac{W_{\text {add }}}{W_{\text {free }}}\right]$

where $\mathrm{W}_{\text {add }}$ and $\mathrm{W}_{\text {free }}$ are the weight loss in the presence and the absence of the inhibitor. The calculated values of I.E. $\%$ and $\theta$ are listed in Table 1.

It is obvious from Table 1 that the values of I.E. increased with increase of inhibitor concentration and the number of ethylene oxide units. The percentage inhibition efficiency of these compounds decreases in the following order: compound V > IV > III > II > I.

Table 1. Effect of ethoxylated fatty ester on the weight loss of copper in $1 \mathrm{M} \mathrm{HCl}$.

\begin{tabular}{|c|c|c|c|c|}
\hline Inhibitors & Conc. (ppm) & Weight loss $\mathrm{mg} \mathrm{cm}^{-2}$ & $\theta$ & $\%$ I.E \\
\hline \multirow[t]{6}{*}{ Compound (I) } & 0.00 & 12.00 & $\begin{array}{l}---- \\
\end{array}$ & ----- \\
\hline & 100 & 7.17 & 0.40 & 40.22 \\
\hline & 300 & 6.56 & 0.45 & 45.34 \\
\hline & 500 & 5.73 & 0.52 & 52.22 \\
\hline & 700 & 5.02 & 0.58 & 58.14 \\
\hline & 900 & 4.46 & 0.63 & 62.86 \\
\hline \multirow[t]{5}{*}{ Compound (II) } & 100 & 6.41 & 0.47 & 46.58 \\
\hline & 300 & 5.30 & 0.56 & 55.83 \\
\hline & 500 & 3.62 & 0.70 & 69.83 \\
\hline & 700 & 3.22 & 0.73 & 73.16 \\
\hline & 900 & 2.84 & 0.76 & 76.33 \\
\hline \multirow[t]{5}{*}{ Compound (III) } & 100 & 5.53 & 0.54 & 53.92 \\
\hline & 300 & 4.68 & 0.61 & 61.00 \\
\hline & 500 & 3.01 & 0.75 & 74.92 \\
\hline & 700 & 2.31 & 0.81 & 80.75 \\
\hline & 900 & 2.22 & 0.82 & 81.50 \\
\hline \multirow[t]{5}{*}{ Compound(IV) } & 100 & 4.89 & 0.59 & 59.25 \\
\hline & 300 & 4.53 & 0.62 & 62.25 \\
\hline & 500 & 2.57 & 0.78 & 78.58 \\
\hline & 700 & 1.71 & 0.86 & 85.75 \\
\hline & 900 & 0.98 & 0.92 & 91.83 \\
\hline \multirow[t]{5}{*}{$\operatorname{compound}(\mathbf{V})$} & 100 & 4.44 & 0.63 & 63.00 \\
\hline & 300 & 3.48 & 0.71 & 71.00 \\
\hline & 500 & 1.84 & 0.85 & 84.66 \\
\hline & 700 & 1.35 & 0.89 & 88.75 \\
\hline & 900 & 0.48 & 0.96 & 96.00 \\
\hline
\end{tabular}

The results could be explained on the basis of the fact that an increase in the concentration of the inhibitor would result in a lowering of the interfacial tension at the metal surface. This lowering in the interfacial tension is thought to cause a decrease of the bulk concentrations of the inhibitor and an increase in its concentration at the metal surface. 


\section{Adsorption isotherm}

The values of surface coverage $\theta$ for different concentrations of the studied compounds (I-V) at $25{ }^{\circ} \mathrm{C}$ have been used to identify the best isotherm to determine the adsorption process. The adsorption of organic adsorbate on the surface of copper electrode is regarded as substitutional process between the organic compound in the aqueous phase $\left(\mathrm{Org}_{\mathrm{aq}}\right)$ and the water molecules adsorbed on the copper surface $\left(\mathrm{H}_{2} \mathrm{O}\right)_{\text {ads }}[22]$.

$\operatorname{Org}_{(\mathrm{sol})}+\mathrm{x}\left(\mathrm{H}_{2} \mathrm{O}\right)_{\mathrm{ads}} \leftrightarrows \mathrm{Org}_{(\text {ads })}+\mathrm{x} \mathrm{H}_{2} \mathrm{O}$

where $\mathrm{x}$ is the size ratio, that is the number of water molecules replaced by one organic molecule. Attempts were made to fit $\theta$ values to various isotherms, including Langmuir, Freundlich, Temkin and Frumkin isotherms. By far the results were best fitted by Temkin adsorption isotherm. The Temkin adsorption isotherm is given by the following equation:

$\ln \mathrm{KC}=\mathrm{a} \theta$

where $\mathrm{k}$ is the equilibrium constant of the adsorption reaction, $\mathrm{C}$ is the inhibitor concentration in the bulk of the solution and a is the molecule interaction parameters depending upon molecular interactions in the adsorption layer and the degree of heterogeneity of the metal surface. The plot of $\theta$ against $\log \mathrm{C}$ for all additives gives straight lines, as shown in Fig. 1. This indicates that these compounds are adsorbed on the surface of copper electrode according to Temkin adsorption isotherm.

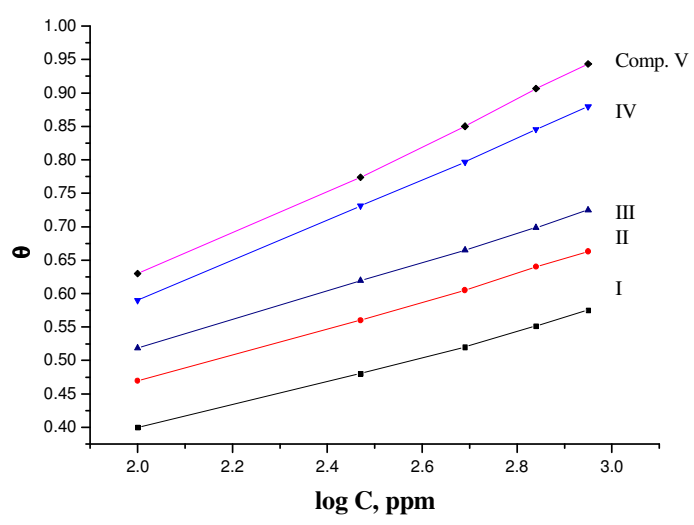

Figure 1. Relation between $\theta$ and the logarithm of the concentration of the inhibitors (Temkin adsorption isotherm).

\section{Galvanostatic polarization}

The effect of addition of ethoxyalted fatty esters on the anodic and cathodic polarization curves of copper in $1.0 \mathrm{M} \mathrm{HNO}_{3}$ solution at $30^{\circ} \mathrm{C}$ was studied. The effect of increased concentration of compound $\mathrm{V}$ is represented in Fig. 2 as an example. However, similar curves were obtained for the other compounds (not 
shown). Corrosion parameters such as corrosion potential $\left(\mathrm{E}_{\text {corr }}\right)$, corrosion current density $\left(\mathrm{I}_{\text {corr }}\right)$, cathodic Tafel constant $(\mathrm{C})$, anodic Tafel slope $\left(\mathrm{b}_{\mathrm{a}}\right)$ and inhibition efficiency (IE), were calculated and given in Table 2.

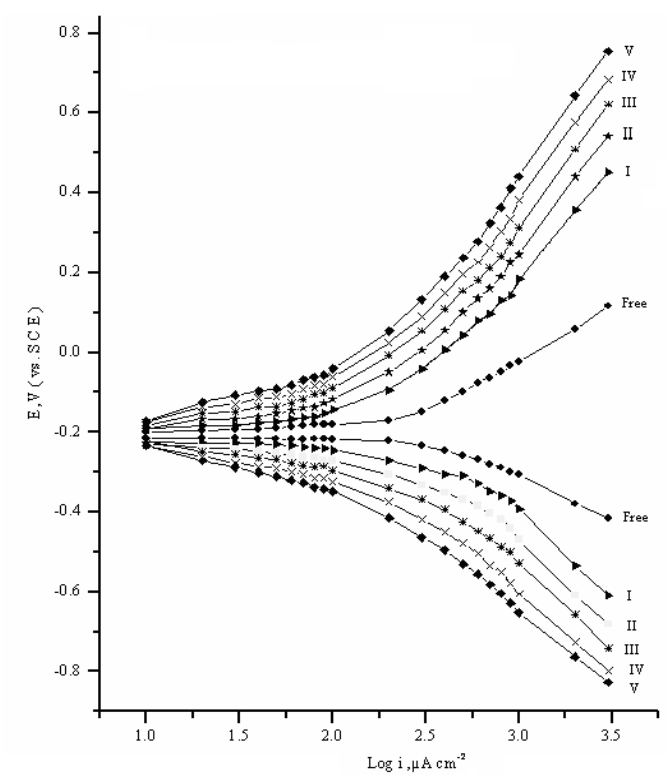

Figure 2. Galvanostatic polarization curves of copper in $1 \mathrm{M} \mathrm{HNO}_{3}$ alone and containing different concentrations of compound $(\mathrm{V})$.

The corrosion current density $\left(\mathrm{I}_{\text {corr }}\right)$ and corrosion potential $\left(\mathrm{E}_{\text {corr }}\right)$ were determined by the intersection of the extrapolating anodic and cathodic Tafel lines. Inhibition efficiency (IE) was calculated using the following equation:

I.E. $=100\left[1-\frac{I_{\text {add }}}{I_{\text {free }}}\right]$

where $I_{\text {free }}$ and $I_{\text {add }}$ are the corrosion current density of copper electrode in the absence and in the presence of the inhibitors, respectively.

Inspection of Table 2 shows:

An increase in both anodic and cathodic Tafel slopes upon addition of inhibitors indicated a mixed anodic and cathodic effect on the corrosion inhibitors mechanism [23]. The corrosion potential is almost unaffected, and $\mathrm{I}_{\text {corr }}$ decreased when the concentration of ethoxylated fatty esters increased, indicating the inhibiting effect of these compounds; the IE increased with increasing of additives and number of ethylene oxide units per molecule of the additive.

The inhibition efficiencies of the five tested compounds measured by the polarization method decreased in the following order: compound $\mathrm{V}>$ VI $>$ III $>$ II $>$ I.

This sequence is in accordance with that obtained from weight loss measurements. 
Table 2. Electrochemical parameters obtained from galvanostatic polarization curves of copper electrode in $1 \mathrm{M} \mathrm{HNO}_{3}$ containing various concentrations of ethoxylated fatty esters.

\begin{tabular}{|lc|ccccc|}
\hline Conc.,ppm & & $\begin{array}{c}-\mathrm{E}_{\text {corr, }} \\
\mathrm{mV}(\mathrm{SCE})\end{array}$ & $\begin{array}{c}\mathrm{I}_{\text {corr }} \\
\mu \mathrm{A} \mathrm{cm}^{-2}\end{array}$ & $\begin{array}{c}\beta \mathrm{a} \\
\mathrm{mV} \mathrm{dec}^{-1}\end{array}$ & $\begin{array}{c}-\beta \mathrm{c} \\
\mathrm{mV} \mathrm{dec}^{-1}\end{array}$ & $\% \mathrm{IE}$ \\
\hline $0.000 \mathrm{M}$ & compound I & 202 & 1.96 & 240 & 145 & --- \\
$100 \mathrm{ppm}$ & $"$ & 208 & 1.22 & 288 & 185 & 37.75 \\
$300 \mathrm{ppm}$ & $"$ & 210 & 1.08 & 325 & 185 & 44.89 \\
$500 \mathrm{ppm}$ & $"$ & 212 & 0.96 & 421 & 225 & 51.02 \\
$700 \mathrm{ppm}$ & $"$ & 215 & 0.88 & 482 & 230 & 55.10 \\
$900 \mathrm{ppm}$ & $"$ & 216 & 0.76 & 527 & 280 & 61.22 \\
\hline $100 \mathrm{ppm}$ & compound II & 196 & 1.06 & 288 & 195 & 45.92 \\
$300 \mathrm{ppm}$ & $"$ & 208 & 0.87 & 327 & 202 & 55.61 \\
$500 \mathrm{ppm}$ & $"$ & 210 & 0.62 & 380 & 215 & 68.37 \\
$700 \mathrm{ppm}$ & $"$ & 216 & 0.54 & 465 & 235 & 72.44 \\
$900 \mathrm{ppm}$ & $"$ & 218 & 0.48 & 515 & 290 & 75.51 \\
\hline $100 \mathrm{ppm}$ & compound III & 209 & 0.92 & 352 & 210 & 53.06 \\
$300 \mathrm{ppm}$ & $"$ & 212 & $0 . .78$ & 398 & 218 & 60.20 \\
$500 \mathrm{ppm}$ & $"$ & 216 & 0.50 & 465 & 275 & 74.48 \\
$700 \mathrm{ppm}$ & $"$ & 219 & 0.41 & 498 & 315 & 79.08 \\
$900 \mathrm{ppm}$ & $"$ & 222 & 0.38 & 560 & 320 & 80.06 \\
\hline $100 \mathrm{ppm}$ & compoundIV & 206 & 0.80 & 286 & 165 & 59.18 \\
$300 \mathrm{ppm}$ & $"$ & 208 & 0.68 & 288 & 198 & 62.22 \\
$500 \mathrm{ppm}$ & $"$ & 215 & 0.42 & 346 & 270 & 78.57 \\
$700 \mathrm{ppm}$ & $"$ & 212 & 0.28 & 452 & 300 & 85.71 \\
$900 \mathrm{ppm}$ & $"$ & 215 & 0.16 & 495 & 315 & 91.83 \\
\hline $100 \mathrm{ppm}$ & compound V & 205 & 0.72 & 350 & 170 & 63.26 \\
$300 \mathrm{ppm} "$ & & 209 & 0.58 & 406 & 225 & 70.41 \\
$500 \mathrm{ppm}$ & $"$ & 205 & 0.30 & 432 & 300 & 84.69 \\
$700 \mathrm{ppm}$ & $"$ & 212 & 0.22 & 502 & 326 & 88.77 \\
$900 \mathrm{ppm}$ & $"$ & 216 & 0.08 & 520 & 320 & 95.92 \\
\hline
\end{tabular}

\section{Inhibition of pitting corrosion}

Potentiodynamic anodic polarization curves of copper electrode were traced in solution of $0.1 \mathrm{M} \mathrm{HNO}_{3}+0.1 \mathrm{M} \mathrm{NaCl}$ (as pitting corrosion agent), devoid and containing different concentrations of ethoxylated fatty esters, at a scanning rate of $1 \mathrm{mV} / \mathrm{sec}$.

The potential was swept from negative potential towards anodic direction up to the pitting potential; no any anodic oxidation peaks are observed in all anodic scan. The pitting potential $\left(\mathrm{E}_{\mathrm{pitt}}\right)$ was taken as the potential at which the current flowing along the passive film increases suddenly to higher values, donating the destruction of passive film and initiation of visible pits. The effect of addition of increasing concentration of ethoxyalted fatty ester on the values of pitting potential is illustrated in Fig. 3. This figure represents the relationship between $\mathrm{E}_{\mathrm{pitt}}$ and logarithmic of ppm concentration of additives. It is clear from this figure that, as the concentration of additives increases, the pitting potential shifted to more positive (noble) direction in according with the following equation:

$$
E_{\text {pitt }}=a+b \log C_{i n h}
$$


where $\mathrm{a}$ and $\mathrm{b}$ are constants depending on the type of used additives. The positive shift of $\mathrm{E}_{\mathrm{pitt}}$ indicates the increased resistance to pitting attack.

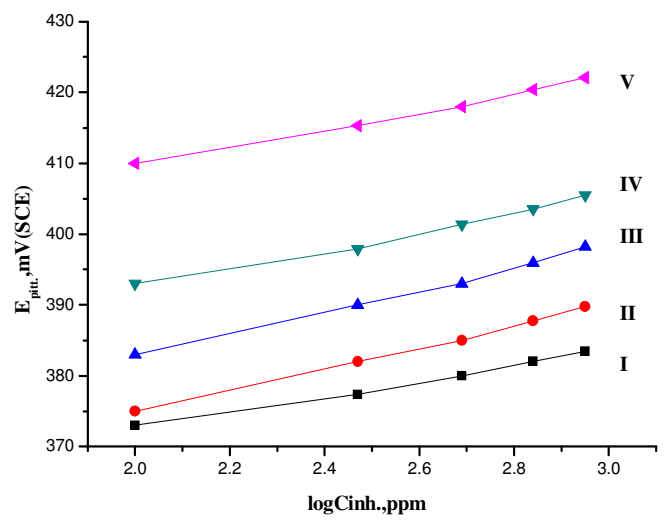

Figure 3. Relationship between pitting corrosion potential of copper and logarithm of the concentration of the inhibitors in the presence of $0.001 \mathrm{M} \mathrm{NaCl}$.

At another same inhibitor concentration, the marked shift of pitting potential in the noble direction (increased resistance to pitting attack) decreases in the following sequence: compound V $>$ VI $>$ III $>$ II $>$ I.

The different techniques used in this study gave the same order of inhibition efficiency but yielded different absolute values, probably due to the different experimental details.

\section{Conclusions}

1- Ethoxylated fatty esters are considered as inhibitors for copper corrosion in 1 $\mathrm{M} \mathrm{HNO}_{3}$. The inhibition efficiency was found to increase by increasing the inhibitor concentration and number of ethylene oxide units.

2- The inhibition is due to the adsorption of inhibitor molecules on the copper surface.

3- The adsorption process follows Temkin adsorption isotherm.

4- Ethoxylated fatty esters provide protection against pitting corrosion of copper in the presence of chloride ions.

\section{References}

1. A. Figual Munoz, J. Garcia Anton, J.L. Guinon, V. Perez Herranz, Electrochim. Acta 50 (2004) 957.

2. G.K.Gomma, Mater. Chem. Phys. 56 (1998) 27.

3. A.S. Fouda, A. Abd El-Aal, A.B. Kandil, Desalination 201 (2006) 216.

4. K.F. Khaled, Appl. Surf. Sci. 255 (2008) 1811.

5. $\quad$ E.M. Sherif, Appl. Surf. Sci. 252 (2006) 8615.

6. E. Galer, D.S. Azambuja, Corros. Sci. 42 (2000) 631.

7. Y.M. Tang, W.Z. Yang, Y.S. Yin, Y. Liu, R. Wan, J.T. Wang, Mater. Chem. Phys. 116 (2009) 479. 
8. L.H. Madkour, M.A. Elmorsi, M.M. Ghoneim, Monatshefte Fur Chemie 126 (1995) 1087.

9. E. Abelev, D. Staeosvetsky, Y. Ein. Eli, Electrochim Acta 52 (2007) 1975.

10. E.M. Sherif, S.M. Park, Corros. Sci. 48 (2006) 4065.

11. A.A. El-Warraky, Ant. Corros. Methods and Mater. 50 (2003) 40.

12. E. Szocs, Gy Vastag, A. Shaban, E. Kalman, Corros. Sci. 47 (2005) 893.

13. M.M. Antonijevic, M.B. Petravic, Int. J. Electrochem. Sci. 3 (2008).

14. S.T. Keera, M.A. Deyab, Colloids Surf. A.: Physicochem. Eng. Aspects 266 (2005)129.

15. I.A. Aiad, N. Negam, J. Surfact. Deterg. 12 (2009) 213.

16. W.Wang, M.L. Free, Corros. Sci. 46 (2004) 2601.

17. M. Abdallah, A.Y. El-Etre, M.F. Moustafa, Port. Electrochim. Acta 27 (2009) 615.

18. M. Abdallah, Corros. Sci. 45 (2003) 2705.

19. P.B. Mathur, T. Vaudencan, Corrosion 38 (1982) 171.

20. S.M. Abd El-Haleem, A.A. Abdel Fattah, W. Tayor, Res. Mech. 30 (1985) 333.

21. A. Cacia, Y. Barakat, S.R. Scheetes, W.H. Wide, S.Yin, J. Colloid Interface Sci. 89 (1982) 219.

22. G. Moretti, G. Quartarone, A. Tassan, A. Zingales, Werkst. Korros. 95 (1994) 641.

23. F. Hanna, G.M. Sherbini, Y. Barakat, Br. Corros. J. 24 (1989) 269. 